\title{
Teacher immediacy and student learning: An examination of lecture/laboratory and self-contained course sections
}

\begin{abstract}
Luke LeFebvre $^{1}$ and Mike Allen ${ }^{2}$
Abstract: This study examined teaching assistant's immediacy in lecture/laboratory and self-contained classes. Two hundred fifty-six students responded to instruments measuring teachers' immediacy behavior frequency, perceptions of instruction quality, and cognitive learning. No significant difference was identified when comparing lecture/laboratory and self-contained teaching assistants' immediacy behaviors. But all students who observed frequent immediate behaviors demonstrated higher affective and cognitive learning. Teaching assistants' ratings had significantly higher levels of facultystudent interaction for self-contained sections but lecture/laboratory sections were significantly higher for student effort/involvement.
\end{abstract}

Keywords: teacher immediacy, introductory course formats, graduate teaching assistants, affective learning, cognitive learning.

Teacher immediacy represents a compositive set of verbal and nonverbal behaviors generating perceptions of psychological closeness with students (Andersen \& Andersen, 1982). Teachers perceived as highly immediate demonstrate "consistent eye contact, movement, vocal variety, gestures, humor, and personalized examples during class; whereas, nonimmediate teachers tend to read from notes, stand behind a podium, use monotone delivery, few gestures, little humor, and abstract examples" (Andersen, 1986, p. 115). An instructor perceived as more immediate is rated by students as more responsive at efforts to influence or modify classroom behavior. Students comply with or conform to the wishes of the more immediate teachers because the perception of immediacy generates more referent, respect, or liking power (Richmond \& McCroskey, 2000).

Teaching assistants, or beginning teachers, in the process of developing strategies for effectiveness in the classroom would benefit by implementing immediacy behaviors (Anderson, 1979; Christophel \& Gorham, 1995; Gorham, 1988; Richmond, Gorham, \& McCroskey, 1987; Sanders \& Wiseman, 1990; Witt \& Wheeless, 2001). According to McCroskey and Richmond (1992), "immediacy creates a more engaging atmosphere for the teacher-student relationship" (p. 102). Not every teacher naturally teaches employs high levels of immediacy, but training could increase instructor immediacy (McCroskey \& Richmond, 1992). "One likely teacher response, when instructing students in the classroom, is to retreat - retreat to reading lectures with as little eye contact as possible with students, retreat to threats of low grades as a motivator, retreat to research and other aspects of the professional role" (McKeachie, 2002b, p. 54). A wide variety of training techniques provide a means for instructors to become more immediate and to develop a level of comfort with the practice (McCroskey \& Richmond, 1992). Research (Collins, 1976) indicates that teachers trained to increase immediacy feel more positive towards teaching. Teaching assistants across academic disciplines trained in immediacy could demonstrate more

\footnotetext{
${ }^{1}$ Program in Speech Communication for the Department of English, Iowa State University, Ames, IA 50011, lefebvre@iastate.edu.

${ }^{2}$ Department of Communication, University of Wisconsin-Milwaukee, Milwaukee, WI, 53201.
} 
positive classroom outcomes for students as well as improved attitudes on the part of the instructors.

This research compares graduate teaching assistant immediacy between formats of courses often used (lecture/laboratory and self-contained). Teaching assistants in a lecture/laboratory format supplement the professor's mass lecture with discussion, exercises, and assignments. The lecture/laboratory format provides a shared responsibility between the course director/lecturer and discussion group leader because there exist two sources of information or instruction in the course. The relationship of the lecturer and the laboratory leader/discussion section instructor are different because the lecturer only deals with the mass of students whereas the discussion section provides a smaller and more intimate setting conducive to discussion and more individualized instruction. The self-contained format, using teaching assistants, combines responsibility for lectures, labs, and all other material included in the course. The self-contained section has only one source of instruction, the teaching assistant.

The present study first describes the context where teaching occurs in the classroom. Next, immediacy is examined as a communicative behavior and related to the classroom. Finally, data from students regarding teaching assistants immediacy, impact on affective and cognitive learning, and the Student Instructional Report II are analyzed and results discussed.

\section{Teaching Context, Immediacy, and Immediacy in the Classroom}

\section{Teaching Context}

The structure of instruction, whether in lecture/laboratory or self-contained instructional setting should influence the perception of the instructor's immediate behaviors. The workload of a teaching assistant ordinarily requires an effort between 360-380 hours per semester for a halftime (50\%) academic year appointment. Teaching assistants conduct instruction in a laboratory situation, year in year out all over the country. Laboratory instruction is widely accepted as important in order for learners to experience phenomena directly and understand the construction of new knowledge (Coppola, 2002). Coppola (2002) maintains laboratory teaching assumes that first-hand experience remains superior to other methods of developing the same skills. Lecture/laboratory teaching assistants supplement the professor's lecture, unlike the stand-alone teaching assistants responsible for both lecture and laboratory information. A typical lecture strives to present a systematic, concise summary of the knowledge (McKeachie, 2002b). Teaching assistants in both the lecture/laboratory and self-contained sections facilitate "learning by doing" laboratory activities. Teaching assistants in the self-contained sections combine the responsibility for the presentation of information in laboratory and lecture.

The course formats of lecture/laboratory and self-contained sections operate in different environments at the institution of study. The course director in both environments, outlines the course, prepares the course objectives, chooses the text, and selects the type and order of the assignments (McKeachie, 2002b). For those students enrolled in lecture/laboratory sections, usually one-third of the educational instruction occurs in a large lecture hall from the course director's weekly lecture. The other two-thirds of instruction consists of two separate hour-long laboratories conducted by the teaching assistant. Students usually identify with the teaching assistant rather than with the lecturer who is perceived as a more distant figure (Wanzer \& McCroskey, 1998). Moreover, students attending the self-contained sections interact only with the teaching assistant during a once-a-week three-hour class. In the self-contained class, the 
student-teacher relationship is more dyadic, blurring the difference between lecture and laboratory. The course director, although responsible for the course objectives, content, and written examinations, most likely never meets the students in a stand-alone section. Therefore, students tend to view the self-contained teaching assistant as individually responsible for the course.

The self-contained section provides the teaching assistant with more autonomy and modification of the course material to fit the style of the instructor. Unlike the lecture/laboratory, self-contained teaching assistants have the opportunity of creating a class built on the notion of a community or team. Envisioning the classroom as a group with a task to accomplish, yet made up of differing personalities coming together to affect the outcome, calls on the teacher to model principles of effective communication and effective leadership (Book \& Putnam, 1992). Teaching assistants instructing in self-contained environments can tailor the lecture, laboratory, and, if they desire, additional information or learning activities into the course. The course director's objectives and text are still utilized, but, unlike the laboratory-teaching assistant viewed as a facilitator, the self-contained teaching assistant assumes some aspects of a course director. Classroom communication of a self-contained section does not have a rigid lecture presentation; students have an opportunity to enhance academic, social, and personal knowledge through student-teacher interaction. Furthermore, students become important contributors to learning, rather than the teacher as the source of all knowledge and as the only one responsible for creating the opportunity to learn (Book \& Putnam, 1992).

Self-contained sections, unlike the lecture/laboratory, have more of an opportunity for teaching assistants to incorporate other experiential, technological, or psychomotor activities into the course. Students gain personal experience not only through speeches, as in the laboratory classes, but by taking part in simulation learning. Experiential learning has both cognitive and motivational goals. Educators hope that abstract concepts become meaningful when students see that they are helpful in describing and understanding "real-life" phenomena (McKeachie, 2002a). McKeachie (2002a) maintains, "experiences in the laboratory will stir up questions in students' minds that will lead to active learning" (p. 246). Technology makes increased learning productively possible, allowing the learners to engage in an intentional process of analyzing and constructing meaning from information and experience. Psychomotor objectives, as Bloom (1964) outlined in his taxonomy, "emphasizes some muscular or motor skill, some manipulation of material and objects, or some act which requires a neuromuscular coordination" (p. 7). Clearly the self-contained teaching assistant has more opportunity to customize the learning environment through a variety of learning activities.

\section{Immediacy}

Mehrabian's foundational work (Mehrabian, 1969, 1971; Wiener \& Mehrabian, 1968) includes verbal immediacy. Wiener and Mehrabian (1968) argue that "the kinds of words used to describe an event transmit information that is complementary, supplementary, or redundant to the information transmitted in other components in the communication, including the explicit verbal content" (p. 2). Clearly, as Mehrabian (1971) indicated previously, immediacy has verbal as well as nonverbal components and both can have an impact on learning in the classroom (McCroskey \& Richmond, 1992). However, it was not until much later that the construct of teacher immediacy broadened to include specific verbal behaviors (Witt \& Wheeless, 2001). The 
term immediacy in this paper uses Mehrabian's originally intended immediacy, a term which includes verbal and nonverbal components.

Immediacy represents verbal or nonverbal expressions often in combination, to communicate relationally the desire to approach another within the context of a relationship (Witt \& Wheeless, 2001). Relational messages are communicated primarily through nonverbal channels, whereas content messages are reflected primarily in verbal channels (Burgoon, Buller, Hale, \& de Turck, 1984; Burgoon \& Saine, 1978). Conceptually then, verbally-based behavior alternation techniques (i.e., content) may be interpreted within the framework of nonverballybased immediacy cues (i.e., relational) (Plax, Kearney, McCroskey, \& Richmond, 1986). Therefore, nonverbal and verbal components of teacher immediacy work in tandem - jointly to express the same message being communicated by the teacher to the receiver.

Nonverbal immediacy incorporates approach behaviors that increase or produce interpersonal closeness, sensory stimulation, and signal warmth and friendliness (Kearney, Plax, \& Wendt-Wasco, 1985). Nonverbal immediacy behaviors such as eye gaze, smiles, nods, relaxed body posture, forward leans, movement, and gestures have the effect of reducing physical and/or psychological distance between teacher and students and apparently increasing affective learning (Andersen, 1979; Christophel \& Gorham, 1995; Hackman \& Walker, 1990; Plax, Kearney, McCroskey, \& Richmond, 1986). Bloom (1956) defined affective learning as "objectives which emphasize a feeling tone, an emotion, or a degree of acceptance or rejection" (p. 7). When classroom teachers employ these nonverbal immediacy strategies, students indicate greater affect for the teacher, greater enjoyment of the class, and increased perceptions of having learned from the course (Richmond et al., 1987). The primary function of teacher's nonverbal behavior is to improve students' affect or liking for the subject matter, teacher, and class, and to increase desire to learn (Richmond \& McCroskey, 2000). The test of this comment was conducted by Allen, Witt, and Wheeless (2006), which indicates that immediacy may be best viewed as a means of increasing affective learning which in turn increases cognitive learning. The relationship suggests that immediacy may provide a means of increasing the motivation of students to study or attend class.

\section{Immediacy in the Classroom}

Learning, particularly that which takes place in the traditional classroom setting, constitutes an interactional process (Richmond, Gorham, \& McCroskey, 1987). People gravitate toward persons and things that they like, evaluate highly, and prefer; avoid or move away from things they dislike, evaluate negatively, or do not prefer (Mehrabian, 1971). A teacher perceived as immediate, communicates a positive attitude (Kearney, Plax, \& Wendt-Wasco, 1985), that leads to increased liking, affiliation, and positive affect on the part of the student (Richmond \& McCroskey, 2000). Immediacy behaviors reduce distances between people, and greater immediacy indicates greater mutual sensory stimulation (Andersen, 1979). Simply, immediate teachers are liked more than nonimmediate teachers (Richmond \& McCroskey, 2000).

A positive interpersonal relationship between teachers and students influences the development of favorable attitudes toward the learning situation (Richmond, Gorham, \& McCroskey, 1987) and the institution (Sweet, 1986; Tinto, 1975). Increased instructor immediacy increases student-teacher communication and interaction. If students communicate more with their teachers, then the student might get the information he or she needs (Richmond \& McCroskey, 2000). Tinto (1975) defines academic integration largely in terms of scholarly 
achievement but includes the student's involvement with the intellectual activities and services offered by the institution. Important to developing social integration are the frequency and quality of contacts students have with instructors (Sweet, 1986).

Parcarella and Terenzini (1980) notes that among the indicators of social integration, frequency of informal contact between students and faculty promotes positive attitudes and commitment. Additionally, the nature or quality of these exchanges has a bearing on student persistence. Most relevant in this regard are conversations with faculty involving intellectual or course-related matters (Parcarella \& Terenzini, 1980). Tinto (1975) maintains that the student dropout, leaving the academic institution, is taken to be the result of the individual's experiences in the academic and social systems of the college. With respect to the academic system of the college, Tinto's Model argues that an individual's integration measures both grade performance and intellectual development during the college years (Tinto, 1975). Therefore, the studentteacher interaction in the classroom provides a critical influence on the student's sense of institutional integration in the educational setting, and the student's perception of affective learning, directly influenced by teacher immediacy, is associated with student retention. Higher affective learning enhances the popularity of the subject matter and increases student enrollment (Andersen, 1986).

Kelley and Gorham (1988) assert that immediacy relates to arousal, and increases attention, improves memory, as well as affective and cognitive learning. Immediate behaviors are seen as triggers to generate student arousal, contributing to student learning. When teachers employ verbal and nonverbal immediacy behaviors, students indicate increased perceptions of having learned from the course (Witt \& Wheeless, 2001). Things vividly presented are more likely to be remembered by students. Hence, immediate teachers arouse students, draw attention to themselves, direct attention to the content, and produce more student learning (McCroskey \& Richmond, 1992). Therefore, teacher immediacy creates student affect for the subject matter. Students become motivated to learn the subject matter because of the teacher's immediate behaviors, will do well in the content, and continue to learn long after the teacher who motivated them is out of the picture (Richmond \& McCroskey, 2000). Plus, the student continues on in the academic institution (Parcarella and Terenzini, 1980; Tinto, 1975).

Immediate strategies constitute a crucial tool for those teaching assistants operating in a self-contained classroom environment. The dynamics of an intact course are drastically altered from that of a lecture/laboratory section, where the professor lectures and teaching assistants supplement the material. In self-contained sections teaching assistants are on their own, most of the time in extended periods, responsible for lectures, labs, and any other material included in the course. If the teaching assistant is not equipped with the immediacy techniques to function in the dynamics of a self-contained classroom no one is there to fill the gap. Therefore, teacher immediacy skills and techniques are even more important for teaching assistants in stand-alone sections. However, both lecture/laboratory and self-contained courses, taught by teaching assistants, can benefit from understanding and utilizing the importance of immediate behaviors. Immediacy creates an approach-oriented behavior signaling accessibility, involvement, arousal, and interest (Andersen, Nussbaum, Pecchioni, \& Grant, 1999). Teacher immediacy creates greater verbal interaction in more immediate classroom conditions (Andersen \& Andersen, 1982). Students are more motivated to remain on task and to learn when they have immediate instructors (Plax \& Kearney, 1999). Also, higher teacher immediacy reduces the status between the student and teacher. This does not mean the teacher is on the same level as the student. It simply means the student will not be intimidated by the teacher's higher status. Therefore, the 
student might be more willing to ask clarifying questions about the content without fear of the teacher (Richmond \& McCroskey, 2000). Immediate teachers encourage students to ask questions in all areas, to ask the teacher and peers to explain reasons or to clarify comments, and to demonstrate respect during interactions (Book \& Putnam, 1992). Therefore, a teaching assistant's immediate behaviors assist in building a classroom where each student's comments are valued and every person is regarded as important.

Cognitive learning refers to the extent to which students achieve factual, conceptual, and critical understanding of course material (Bloom, 1956). A number of studies (Richmond, Gorham, \& McCroskey, 1987; Kelley \& Gorham, 1988) have investigated a link between teacher immediacy and cognitive performance by the student. A recent meta-analytic study (Witt, Wheeless, \& Allen, 2006) indicates that immediacy has a negligible relationship to cognitive learning. Research has not demonstrated a strong association with cognitive learning but has clearly demonstrated a number of other positive outcomes.

Immediacy research has as many as 200 studies reporting the positive associations and various classroom outcomes such as student motivation, student satisfaction, and student learning (Witt, Schrodt, \& Turman, 2010). However, there are potential drawbacks of teacher immediacy. Immediate instructors may be perceived as not having control over the classrooms (Richmond \& McCroskey, 2000). However, immediate instructors generating high student affect seldom have discipline or classroom control problems (Richmond \& McCroskey, 2000). The entire class group is "in synch" and is coordinated with the instructor (Andersen, 1986).

Murray (1997) showed that enthusiastic teachers move around, make eye contact with students, and use more gestures and vocal variation, and teachers could learn these behaviors. Preparing beginning teaching assistants to increase immediacy requires that trainees understand immediate behavior. However, not everyone will incorporate the same immediate behaviors in the same way. Teaching assistants need to select and use those behaviors with which they are most comfortable. A teacher utilizing a behavior that seems uncomfortable appears awkward to students rather than immediate. False immediacy becomes evaluated as worse than low immediacy (Richmond \& McCroskey, 2000).

The literature on teacher immediacy does not demonstrate a clear understanding of how the classroom environment influences students' perceptions of the instructor due to class settings (i.e., lecture/laboratory or self-contained). The examination of course formats has received minimal attention in the extant literature (e.g., Gray, Buerkel-Rothfuss, \& Yerby, 1986; Todd, Tilson, Cox, \& Malinauskas, 2000; Wildermuth, French, \& Fredrick, 2013). Todd and colleagues investigation examined undergraduate students' perceptions of teacher immediacy in lecture/lab and self-contained sections of the introductory course. These authors reported no essential difference except that students in self-contained sections did identify instructors as more verbally immediate. Therefore, the purpose of this study was to further examine the relationship between student perceptions of immediacy behaviors, affective and cognitive learning, and student ratings of instruction. The following are research questions:

$\mathrm{RQ}_{1}$ : Does any difference exist between immediacy scales comparing lecture/laboratory and self-contained sections?

$\mathrm{RQ}_{2}$ : Does any difference exist in affective learning measures between lecture/laboratory and self-contained sections exist? 
$\mathrm{RQ}_{3}$ : Does any difference exist in cognitive learning between lecture/laboratory and self-contained sections?

$\mathrm{RQ}_{4}$ : What correlation exists, if any, between student instructor rating (SIR II) comparing lecture/laboratory and self-contained sections?

\section{Methods}

\section{Participants and Procedures}

Two hundred and fifty-six students enrolled in introductory public speaking at a midwestern public university participated in this study. Essentially, the introductory public speaking course is where students create, perform, analyze, and develop public speaking skills (Morreale, Hugenberg, \& Worley, 2006). Teacher immediacy, cognitive and affective learning and student rating data were collected during the last two weeks of the semester. The data was sealed and unopened until grades had been submitted to avoid influencing the results. A total of 321 surveys were returned, $256(80 \%)$ were usable. The unusable surveys were incomplete. The distribution of respondents by class level was $36 \%$ freshmen, $28 \%$ sophomore, $20 \%$ juniors, and $13 \%$ seniors. Of the students in the communication course being analyzed $43 \%$ were fulfilling a major/minor requirement, $44 \%$ a college requirement, $11 \%$ an elective, and $2 \%$ other. A total of 117 students were enrolled in a single lecture with ten different laboratory sections; 139 students were enrolled in ten different self-contained sections. Class size in the laboratory was limited to 22 students and self-contained sections was limited to 24 students.

Three instruments for measuring (a) teacher immediacy, (b) affective learning, and (c) student rating of the instructor (SIR II) were utilized. The students' cognitive learning was measured following the teaching assistants' submission of grades at the completion of the semester.

\section{Measurement of Immediacy}

The students' score on the Nonverbal Immediacy Behavior Scale (Richmond, McCroskey, \& Johnson, 2003) measured teacher's immediacy, refer to Appendix 1. The Immediacy Behavior Scale is a descriptive instrument comprising 26 items that require a frequency response of 1 (never) to 5 (very often). For a given instructor, this scale provides a lowest possible score of 0 and a highest possible score of 130. Instructors rated as highly immediate have a score greater than 109 , those considered to have low immediacy have a score of less than 79. Alpha reliability for the scale was .85 .

\section{Measurement of Affective Learning}

The Affective Learning Measure (McCroskey, 1994) assessed affect toward instructor, class' content, likelihood of taking future courses in this content area, and likelihood of taking future courses with this specific teacher. Sixteen questions with a seven point rating scale assessed affect toward communication and instruction. See questionnaire in Appendix 2. Scores should be between four and twenty-eight; higher scores indicate higher affective levels. The alpha reliability scale for teacher evaluation was .85 . The alpha reliability scale for affective 
learning scale was .81. The alpha reliability scale for future enrollment by student in content area was .91 . The alpha reliability scale for enrollment in future course by instructor was .92 .

\section{Measurement for Cognitive Learning}

Cognitive learning was assessed using the student letter grade achieved in the course. Letter grades are determined as follows: $\mathrm{A}=4.00, \mathrm{~A}-=3.67, \mathrm{~B}+=3.33, \mathrm{~B}=3.00, \mathrm{~B}-=2.67, \mathrm{C}+$ $=2.33, \mathrm{C}=2.00, \mathrm{C}-=1.67, \mathrm{D}+=1.33, \mathrm{D}=1.00, \mathrm{D}-=0.67$, and $\mathrm{F}=0.00$.

\section{Measurement of Student Ratings of Instruction}

The Student Instructional Report II (SIR II) developed by the Educational Testing Service was used to measure student ratings of instructors. According to Moore et al. (1996) over 150 colleges and universities nationwide have used this evaluative instrument in order to assess student experiences. The SIR II consists of 45 items that measure different aspects of student experiences and characteristics. The SIR II is comprised of ten sections, the following seven were used for this study: Course Organization and Planning $(S D=.46)$, Communication $(S D=$ $.44)$, Faculty/Student Interaction $(S D=.48)$, Assignments, Exams, and Grading $(S D=.44)$, Course Outcomes $(S D=.48)$, Student Effort and Involvement $(S D=.40)$, and Overall Evaluation $(S D=.52)$. Means were compared ( $t$ test) between teaching assistants for lecture/laboratory and self-contained for the seven SIR II sections.

\section{Data Analysis}

Analyses evaluated the relationship of immediacy to student ratings of instructors and measurement of affective and cognitive learning. Ratings between self-contained and lecture/laboratory teaching assistant sections were compared. The purpose of comparing these sections to each other is to determine if one type, either intact or lecture/laboratory teaching assistants, generates more immediacy, higher affective and cognitive understanding of course material, and how the instructor is perceived by his/her students.

\section{Results}

\section{Research Question One}

Teaching assistants in lecture/laboratory formats $(M=97.74, S D=9.99, N=117)$ were not significantly different $(t=.15, d f=254, p=.88)$ from teaching assistants in self-contained sections $(M=97.55, S D=10.50, N=139)$ on the level of perceived immediacy.

Teaching assistants in lecture/laboratory formats $(M=22.61, S D=5.62, N=117)$ were not significantly different $(t=.28, d f=254, p=.78)$ from teaching assistants in self-contained sections $(M=22.42, S D=5.06, N=139)$ on teacher evaluation.

\section{Research Question Two}

Teaching assistants in lecture/laboratory formats $(M=22.17, S D=4.70, N=117)$ were not significantly different $(t=1.66, d f=254, p=.10)$ from teaching assistants in self-contained sections $(M=22.15, S D=5.06, N=139)$ on the level of affective learning. 
Students enrolled in lecture/laboratory formats $(M=17.25, S D=6.64, N=117)$ were more likely to enroll in a similar courses of the same content, demonstrating a significant difference $(t=2.73, d f=254, p=.02)$ from teaching assistants in self-contained sections $(M=$ $15.14, S D=7.43, N=139)$.

Teaching assistants in lecture/laboratory formats $(M=19.43, S D=7.56, N=117)$ were not significantly different $(t=1.59, d f=254, p=.11)$ from teaching assistants in self-contained sections $(M=17.89, S D=7.70, N=139)$ on likelihood of a student enrolling in another course taught by the same instructor, but students from both groups are likely to enroll in a future courses taught by the same instructor.

\section{Research Question Three}

The study found teacher immediacy correlated positively with cognitive learning. When students experienced high teacher immediacy, it correlated to increased cognitive learning as evidenced by a higher grade in the course $(r=.21, p<.001, N=256)$. Other variables did not generate a significant correlation. See Table 1.

Table 1

Correlation Coefficients

\begin{tabular}{|c|c|c|c|c|c|c|}
\hline & $\begin{array}{c}\text { Teacher } \\
\text { Evaluation }\end{array}$ & $\begin{array}{l}\text { Affective } \\
\text { Learning }\end{array}$ & $\begin{array}{c}\text { Future } \\
\text { Content }\end{array}$ & $\begin{array}{c}\text { Future } \\
\text { Teacher }\end{array}$ & Cognitive & Laboratory \\
\hline Immediacy & $\begin{array}{c}.57 \\
p<.01\end{array}$ & $\begin{array}{c}.43 \\
p<.01\end{array}$ & $\begin{array}{c}.21 \\
p<.01\end{array}$ & $\begin{array}{c}.45 \\
p<.01\end{array}$ & $\begin{array}{c}.21 \\
p<.00\end{array}$ & $\begin{array}{c}-.01 \\
p=.88\end{array}$ \\
\hline $\begin{array}{l}\text { Teacher } \\
\text { Evaluation }\end{array}$ & & $\begin{array}{c}.69 \\
p<.01\end{array}$ & $\begin{array}{c}.25 \\
p<.01\end{array}$ & $\begin{array}{c}.63 \\
p<.01\end{array}$ & $\begin{array}{c}.24 \\
p=.00\end{array}$ & $\begin{array}{c}-.02 \\
p=.10\end{array}$ \\
\hline $\begin{array}{l}\text { Affective } \\
\text { Learning }\end{array}$ & & & $\begin{array}{c}.37 \\
p<.01\end{array}$ & $\begin{array}{c}.49 \\
p<.01\end{array}$ & $\begin{array}{c}.23 \\
p<.01\end{array}$ & $\begin{array}{c}-.10 \\
p=.10\end{array}$ \\
\hline $\begin{array}{c}\text { Future } \\
\text { Content }\end{array}$ & & & & $\begin{array}{c}.51 \\
p<.01\end{array}$ & $\begin{array}{c}.10 \\
p=.10\end{array}$ & $\begin{array}{c}-.15 \\
p=.02\end{array}$ \\
\hline $\begin{array}{l}\text { Future } \\
\text { Teacher }\end{array}$ & & & & & $\begin{array}{c}.16 \\
p<.01\end{array}$ & $\begin{array}{c}-.10 \\
p=.11\end{array}$ \\
\hline Cognitive & & & & & & $\begin{array}{c}.06 \\
p=.34\end{array}$ \\
\hline
\end{tabular}

\section{Research Question Four}

The SIR II found no significant difference in five of the seven topics: Course Organization and Planning (lecture/laboratory $M=4.18$; self-contained $M=4.19$ ), Communication (lecture/laboratory $M=4.18$; self-contained $M=4.19$ ), Assignments, Exams, and Grading (lecture/laboratory $M=3.73$; self-contained $M=3.73$ ), Course Outcomes (lecture/laboratory $M=3.58$; self-contained $M=3.49$ ), and Overall Evaluation (lecture/laboratory $M=3.85$; self-contained $M=3.91$ ). The comparison of Faculty Student Interaction (lecture/laboratory $M=4.01$; self-contained $M=4.13$ ) was found to be significantly higher $(p<.05)$ for the self-contained sections. For the lecture/laboratory sections, Student Effort 
and Involvement (lecture/laboratory $M=3.60$; self-contained $M=3.50$ ) was significantly higher $(p<.05)$ than for the self-contained classes. See chart in Table 2.

Table 2

Student Instructor Rating II

\begin{tabular}{|l|c|c|c|c|}
\cline { 2 - 5 } \multicolumn{1}{c|}{} & \multicolumn{2}{c|}{$t$-tests } & \multicolumn{2}{c|}{ Mean(s) } \\
\hline Topics & $t$ & $S D$ & Lec/Lab & Self-con \\
\hline Course Organization and Planning & 0.17 & .46 & 4.18 & 4.19 \\
\hline Communication & 0.20 & .44 & 4.18 & 4.19 \\
\hline Faculty/Student Interaction & 2.00 & .48 & 4.01 & 4.13 \\
\hline Assignments, Exams, and Grading & 0.00 & .44 & 3.73 & 3.73 \\
\hline Course Outcomes & 1.50 & .48 & 3.58 & 3.49 \\
\hline Student Effort and Involvement & 2.00 & .40 & 3.60 & 3.50 \\
\hline Overall Evaluation & 1.00 & .52 & 3.85 & 3.91 \\
\hline
\end{tabular}

\section{Discussion}

This investigation identified no significant difference in immediacy between teaching assistants instructing lecture/laboratory or self-contained course sections. However, the impact of teacher immediacy influenced the teacher-student relationship in both settings. Students rated their teaching assistants more positively as immediacy behaviors increased. Moreover, student perceptions of immediate behaviors by their teaching assistants impacted both affective and cognitive learning. The data indicated no significant difference between lecture/laboratory and self-contained classes for affective learning. The results indicate a universal importance for instructor immediacy regardless of course format. This study reported that lecture/laboratory and self-contained sections do not differ in their influence on student cognitive learning; however, immediacy did influence cognitive learning among students. Students demonstrating higher levels of cognitive learning rated instructors as higher in immediacy.

Recognizing that immediate teachers influence positive perceptions of interpersonal closeness, sensory stimulation, liking, warmth, and friendliness is important for course directors or professors who are managing their teaching assistants. Taken together, what a teacher thinks he/she does may be of marginal interest, but what is of critical concern is what students think the teacher does and what impact those perceptions have on other meanings stimulated in the mind of the student (Richmond, 1990). Immediacy has a direct influence on what students perceive in the classroom. The SIR II results found that students of lecture/laboratory classes put forth more effort and involvement throughout the course.

Instructors generating high student affect not only improve self-esteem, feel liked by their students, and receive higher student evaluations; they also generate more affective learning for the subject matter and their academic discipline (Andersen, 1986). Therefore, the findings of this study affirm the importance of providing training to acquaint teaching assistants in the development of immediate skills. Allowing teaching assistants to learn about and practice immediate behaviors while they develop their own teaching style would aid in building teacher confidence and, most importantly, better serve students in their learning. 
Teaching assistants of lecture/laboratory and self-contained courses did not demonstrate significant differences in immediacy ratings. Whether a teaching assistant is instructing a laboratory or self-contained section the ability to perform immediate behaviors becomes critical in how students view the instructors' roles, abilities, and qualifications. Therefore, teaching assistants prepared to implement immediate techniques possess a clear advantage for developing a learning community within the classroom.

The student ratings of instructor indicated significant differences among lecture/laboratory and self-contained sections in two areas: (a) Student Effort and Involvement and (b) Faculty/Student Interaction. Students in lecture/laboratory sections reported having put forth more effort and involvement throughout the course, than that of self-contained sections. Because the lecture/laboratory course structure consists of one lecture and two laboratory meetings per week, the students may have felt a greater effort and involvement was necessary compared to students who met once weekly in the three-hour self-contained course.

Students in the self-contained course sections reported a higher level of faculty-student interaction than did students in lecture/laboratory classes. Students may view self-contained teaching assistants as more available than teaching assistants in laboratory settings. Because laboratory teaching assistants have laboratories scheduled back-to-back, they have little time following a class to answer student questions or offer extra help. In contrast, teaching assistants in self-contained classes are available prior to and after classes to assist students. Further, the three-hour block of time allows ample student-teacher interaction opportunities.

Thus, whether for pragmatic reasons such as increased student enrollments and increased funding, or for philosophical goals such as a better-educated society, the mechanisms that generate high student affect should remain a central concern (Andersen, 1986). Should institutions need to make a financial decision to provide an introductory course offering in a lecture/laboratory format over the cost of employing part-time faculty for self-contained sections the primary concern appears to not be course format but teacher immediacy skill development.

This study examined 20 different sections of one course. The teaching assistants are not a random selection and, therefore, generalizations should be made with caution. The findings are limited to first and second year teaching assistants, not instructors with greater experience. The impact of immediacy and associated training may be greater with teaching assistants and may be less effective with more experienced instructors.

It would be interesting to follow the students in this study to determine if those who perceived higher levels of teacher immediacy showed greater institutional integration-continue to take courses in the department and university, complete a degree, and evolve into supportive alumni. An examination of a post-Tinto model of institutional integration could begin to assess why graduates contribute to their former colleges or universities.

Understanding the positive effects of immediacy for the college or university, administrators, professors, and teaching assistants ultimately benefits the students. Immediacy increases the likelihood of student affect for the subject, recall of material learned, enrollment in similar courses, institutional integration, and degree completion. In the short run, higher affective learning enhances the popularity of the subject matter and increases student enrollments. In the long run, higher affect is the avenue to lifelong learning, more general support of education, and a better society (Andersen, 1986). Teaching assistants equipped with immediate skills enhance the teacher-student relationship contributing to both short and long term benefits for students and the university. 


\section{Appendices}

\section{Appendix 1. Nonverbal Immediacy Scale - Self-Report}

DIRECTIONS: The following statements describe the ways some instructors interact while talking with or to students. Please indicate in the space to the left of each item the degree to which you believe the statement applies to your instructor. Please use the following 5-point scale:

\section{$1=$ Never $; 2=$ Rarely $3=$ Occasionally $; 4=$ Often $; 5=$ Very Often}

1. Uses hands and arms to gesture while talking to the class.

2. Touches students on the shoulder or arm while talking to them.

3. Uses monotone or dull voice while talking to the class.

4. Looks at board or notes when talking to the class.

5. Uses very few gestures when talking to the class.

6. Has a relaxed body position when talking to the class.

7. Smiles at individual students in the class.

8. Avoids eye contact with the class while talking.

9. Has a very tense body position when talking to the class.

10. Sits on a desk or in a chair when teaching.

11. Voice is monotonous or dull when talking to the class.

12. Uses a variety of vocal expressions when talking to the class.

13. Gestures when talking to the class.

14. Animated when talking to the class.

15. Bland facial expressions when talking to the class.

16. Moves closer to students when talking to them.

17. Looks directly at students when talking to them.

18. Stands behind a podium or desk when teaching.

19. Has a lot of vocal variety when talking to the class.

20. Avoids gesturing while teaching.

21. Moves around the room when teaching.

22. Maintains eye contact with the class when teaching.

23. Stands behind a podium or desk when teaching.

24. Avoids eye contact with students in the class.

25. Smiles at the class as a whole, not just individual students.

26. Avoids touching students while talking with them. 
LeFebvre, L., \& Allen, M.

\section{Appendix 2. Affective Learning Measure}

Please circle the number that best represents your feelings. The closer a number is to the item/adjective the more you feel that way.

Overall, the instructor I have in the class is:

\begin{tabular}{|c|c|c|c|c|c|c|c|c|}
\hline 1. $\mathrm{Bad}$ & 1 & 2 & 3 & 4 & 5 & 6 & 7 & Good \\
\hline 2. Valuable & 1 & 2 & 3 & 4 & 5 & 6 & 7 & Worthless \\
\hline 3. Unfair & 1 & 2 & 3 & 4 & 5 & 6 & 7 & Fair \\
\hline 4. Positive & 1 & 2 & 3 & 4 & 5 & 6 & 7 & Negative \\
\hline
\end{tabular}

I feel the class' content is:

\begin{tabular}{|c|c|c|c|c|c|c|c|c|}
\hline 5. Bad & 1 & 2 & 3 & 4 & 5 & 6 & 7 & Good \\
\hline 6. Valuable & 1 & 2 & 3 & 4 & 5 & 6 & 7 & Worthless \\
\hline 7. Unfair & 1 & 2 & 3 & 4 & 5 & 6 & 7 & Fair \\
\hline 8. Positive & 1 & 2 & 3 & 4 & 5 & 6 & 7 & Negative \\
\hline
\end{tabular}

My likelihood of taking future courses in this content area is:

$\begin{array}{lllllllll}\text { 9. Unlikely } & 1 & 2 & 3 & 4 & 5 & 6 & 7 & \text { Likely } \\ \text { 10. Possible } & 1 & 2 & 3 & 4 & 5 & 6 & 7 & \text { Impossible } \\ \text { 11. Improbable } & 1 & 2 & 3 & 4 & 5 & 6 & 7 & \text { Probable } \\ \text { 12. Would } & 1 & 2 & 3 & 4 & 5 & 6 & 7 & \text { Would Not }\end{array}$

My likelihood of taking future courses with this specific teacher is:

\begin{tabular}{|c|c|c|c|c|c|c|c|c|}
\hline 13. Unlikely & 1 & 2 & 3 & 4 & 5 & 6 & 7 & Likely \\
\hline 14. Possible & 1 & 2 & 3 & 4 & 5 & 6 & 7 & Impossible \\
\hline 15. Improbable & 1 & 2 & 3 & 4 & 5 & 6 & 7 & Probable \\
\hline 16. Would & 1 & 2 & 3 & 4 & 5 & 6 & 7 & Would Not \\
\hline
\end{tabular}




\section{References}

Allen, M., Witt, P., \& Wheeless, L. (2006). The Role of Teacher Immediacy as a Motivational Factor in Student Learning: Using Meta-analysis to Test a Causal Model. Communication Education, 55, 21-31. doi: 10.1080/03634520500343368

Anderson, J. (1979). Teacher Immediacy as a Predictor of Teaching Effectiveness. In D. Nimmo (Ed.), Communication Yearbook 3 (pp. 543-559). New Brunswick, NJ: Transaction Books.

Andersen, J. (1986). Instructor Nonverbal Communication: Listening to Our Silent Messages. New Directions for Teaching and Learning, 26, 41-49. doi: 10.1002/tl.37219862607

Andersen, P., \& Andersen, J. (1982). Nonverbal Immediacy in Instruction. In L. Barker (Ed.), Communication in the Classroom (pp. 98-120). Englewood Cliffs, NJ: Prentice-Hall.

Andersen, J., Nussbaum, J., Pecchioni, L., \& Grant, J. (1999). Interaction Skills in Instructional Settings. In A. Vangelisti, J. Daly, \& Friedrich (Ed.), Teaching Communication: Theory, Research, and Methods (pp. 359-374). Mahwah, NJ: Lawrence Erlbaum.

Bloom, B. (1956). A Taxonomy of Educational Objectives. New York: Longmans, Green.

Book, C., \& Putnam, J. (1992). Organization and Management of a Classroom as a Learning Community Culture. In V. Richmond \& J. McCroskey (Eds.), Power in the Classroom: Communication, Control, and Concern (pp. 101-119). Hillsdale, NJ: Erlbaum.

Burgoon, J., Buller, D., Hale, J., \& de Turck, M. (1984). Relational Messages Associated with Nonverbal Behaviors. Human Communication Research, 10, 351-378. doi: 10.1111/j.14682958.1984.tb00023.x

Burgoon, J., \& Saine, T. (1978). The Unspoken Dialogue: An Introduction to Nonverbal Communication. Boston: Houghton Mifflin.

Christophel, D., \& Gorham, J. (1995). A Test-retest Analysis of Student Motivation, Teacher Immediacy and Perceived Sources of Motivation and Demotivation in College Classes.

Communication Education, 44, 292-305. doi: 10.1080/03634529509379020

Collins, M. (1976). The Effects of Training for Enthusiasm on the Enthusiasm Displayed by Preservice Elementary Teachers. Education, 33, 130-337.

Coppola, B. (2002). Laboratory Instruction: Ensuring an Active Learning Experience. In W. McKeachie (Eds.), Teaching Tips: Strategies, Research, and Theory for College and University Teachers (pp. 235-244). Boston: Houghton Mifflin.

Gorham, J. (1988). The Relationship Between Verbal Teacher Immediacy and Student Learning. Communication Education, 37, 40-53. doi: 10.1080/03634528809378702 
Gray, P. L., Buerkel-Rothfuss, N. L., \& Yerby, J. (1986). PSI-based and Lecture-recitation Formats of Instruction in the Introductory Speech Communication Course. Communication Education, 35 (2), 111-125. doi: 10.1080/03634528609388329

Hackman, M., \& Walker, K. (1990). Instructional Communication in the Televised Classroom: The Effects of System Design and Teacher Immediacy on Student Learning and Satisfaction. Communication Education, 39, 196-206. doi: 10.1080/03634529009378802

Jordan, F. (1989). An Examination of the Relationship Between Perceived Verbal and Paralinguistic Immediacy and Accommodation to Perceived Cognitive Learning. Unpublished doctoral dissertation, West Virginia University, Morgantown.

Kearney, P., Plax, T., \& Wendt-Wasco, N. (1985). Teacher Immediacy for Affective Learning in Divergent Classes. Communication Quarterly, 33, 61-74. doi: 10.1080/01463378509369579

Kelly, D., \& Gorham, J. (1988). Effects of Immediacy on Recall of Information. Communication Education, 37, 198-207. doi: 10.1080/03634528809378719

McCroskey, J. C. (1994). Assessment of Affect Toward Communication and Affect Toward Instruction in Communication. In S. Morreale \& M. Brooks (Eds.), 1994 SCA Summer Conference Proceedings and Prepared Remarks: Assessing College Student Competence in Speech Communication. Annandale, VA: Speech Communication Association.

McCroskey, J., \& Richmond, V. (1992). Increasing Teacher Influence Through Immediacy. In V. Richmond \& J. McCroskey (Eds.), Power in the Classroom: Communication, Control, and Concern (pp. 101-119). Hillsdale, NJ: Erlbaum.

McKeachie, W. (2002a). Facilitating Experiential Learning: Service Learning, Fieldwork, and Collaborative Research. In W. McKeachie (Eds.), Teaching tips: Strategies, Research, and Theory for College and University Teachers (pp. 245-249). Boston: Houghton Mifflin.

McKeachie, W. (2002b). How to Make Lectures More Effective. In W. McKeachie (Eds.), Teaching tips: Strategies, Research, and Theory for College and University Teachers (pp. 5269). Boston: Houghton Mifflin.

Mehrabian, A. (1969). Some Referents and Measures of Nonverbal Behavior. Behavioral Research Methods and Instruments, 1, 213-217.

Mehrabian, A. (1971). Verbal and Nonverbal Interaction of Strangers in a Waiting Situation. Journal of Experimental Research in Personality, 5, 127-138.

Menzel, K., \& Carrell, L. (1999). The Impact of Gender and Immediacy on Willingness to Talk and Perceived Learning. Communication Education, 48, 31-40. doi:

$10.1080 / 03634529909379150$ 
Moore, A., Masterson, J., Christophel, D., \& Shea, K. (1996). College Teacher Immediacy and Student Ratings of Instruction. Communication Education, 45, 29-39. doi:

$10.1080 / 03634529609379030$

Morreale, S. P., Hugenberg, L., \& Worley, D. (2006). The Basic Communication Course at U.S. Colleges and Universities in the $21^{\text {st }}$ Century: Study VII. Communication Education, 55(4), 415 437. doi: $10.1080 / 03634520600879162$

Murry, H. (1997). Effective Teaching Behaviors in the College Classroom. In R. Perry \& J. Smart (Eds.), Effective Teaching in Higher Education: Research and Practice (pp. 171-204). New York: Agathon.

Norton, R. (1986). Communicator Style in Teaching: Giving Good Form to Content. New Directions for Teaching and Learning, 26, 33-40. doi: 10.1002/t1.37219862606

Pascarella, E., \& Terenzini, P. (1980). Predicting Freshman Persistence and Voluntary Dropout Decisions From a Theoretical Model. Journal of Higher Education, 52, 197-210.

Plax, T., \& Kearney, P. (1999). Classroom Management: Contending with College Student Discipline. In A. Vangelisti, J. Daly, \& Friedrich (Ed.), Teaching Communication: Theory, Research, and Methods (pp. 269-286). Mahwah, NJ: Lawrence Erlbaum.

Plax, T., Kearney, P., McCroskey, J., \& Richmond, V. (1986). Power in the Classroom VI: Verbal Control Strategies, Nonverbal Immediacy, and Affective Learning. Communication Education, 35, 43-55. doi: 10.1080/03634528609388318

Richmond, V. (1990). Communication in the Classroom: Power and Motivation. Communication Education, 39, 181-195. doi: 10.1080/03634529009378801

Richmond, V., Gorham, J., \& McCroskey, V. (1987). The Relationship Between Selected Immediacy Behaviors and Cognitive Learning. In M. McLaughlin (Ed.), Communication yearbook 10 (pp. 574-590). Newbury Park, CA: Sage.

Richmond, V., \& McCroskey, J. (2000). Nonverbal Behavior in Interpersonal Relations. Boston: Allyn \& Bacon.

Richmond, V. P., McCroskey, J. C., \& Johnson, A. E. (2003). Development of the Nonverbal Immediacy Scale (NIS): Measures of Self- and Other-perceived Nonverbal Immediacy. Communication Quarterly, 51, 502-515. doi: 10.1080/01463370309370170

Sanders, J., \& Wiseman, R. (1990). The Effects of Verbal and Nonverbal Teacher Immediacy on Perceived Cognitive, Affective, and Behavioral Learning in the Multicultural Classroom. Communication Education, 39, 341-353. doi: 10.1080/03634529009378814 
Sweet, R. (1986). Student Dropout in Distance Education: An Application of Tinto's Model. Distance Education, 7, 201-213. doi: 10.1080/0158791860070204

Tinto, V. (1975). Dropout from Higher Education: A Theoretical Synthesis of Recent Research. Review of Educational Research, 45, 89-125. doi: 10.3102/00346543045001089

Titsworth, B. S. (2004). Students' Notetaking: The Effects of Teacher Immediacy and Clarity. Communication Education, 53 (4), 305-320. doi: 10.1080/0363452032000305922

Todd, T.S., Tilson, L. D., Cox, S. A., \& Malinauskas, B. (2000). Assessing the Perceived Effectiveness of the Basic Communication Course: An Examination of Mass-lecture Format Versus the Self-contained Format. Journal of the Association of Communication Administration, 29, 185-195.

Wanzer, M. B., \& McCroskey, J. C. (1998). Teacher Socio-communicative Style as a Correlate of Student Affect Toward Teacher and Course Material. Communication Education, 47 (1), 43 52. doi: 10.1080/03634529809379109

Wiener, M., \& Mehrabian, A. (1968). Language Within Language: Immediacy, a Channel in Verbal Communication. New York: Appleton-Century-Crofts.

Wildermuth, S. M., French, T., \& Fredrick, E. (2013). Finding the Right Fit: Assessing the Impact of Traditional v. Large Lecture/small Lab Course Formats on a General Education Course. International Journal for the Scholarship of Teaching and Learning, 7 (1). Retrieved from http://academics.georgiasouthern.edu/ijsotl/v7n1/articles/PDFs/acc\%20Art_Wildermuth\%20et\% 20al.pdf

Witt, P., Schrodt, P., \& Turman, P. (2010). Instructor Immediacy: Creating Connections Conducive to Classroom Learning. In D. L. Fassett \& J. T. Warren (Eds.), The Sage Handbook of Communication and Instruction (pp. 201-219). Thousand Oaks, CA: Sage.

Witt, P., \& Wheeless, L. (2001). An Experimental Study of Teachers' Verbal and Nonverbal Immediacy and Students' Affective and Cognitive Learning. Communication Education, 50, 327-342. doi: 10.1080/03634520109379259

Witt, P., Wheeless, L., \& Allen, M. (2004). A Meta-analytical Review of the Relationship Between Teacher Immediacy and Student Learning. Communication Monographs, 71(2), 184207. doi: $10.1080 / 036452042000228054$

Witt, P., Wheeless, L., \& Allen, M. (2006). The Relationship Between Teacher Immediacy and Student Learning: A Meta-analysis. In B. M. Gayle, R. W. Preiss, N. Burrell, \& M. Allen (Eds.), Classroom Communication and Instructional Processes: Advances Through Meta-analysis (pp. 149-168). Mahwah, NJ: Lawrence Erlbaum. 